$\begin{array}{r}\text { DARMABAKTI CENDEKIA: } \\ \text { Journal of Community Service and Engagements } \\ \text { www.e-journal.unair.ac.id/index.php/DC } \\ \hline\end{array}$

\section{STRENGTHENING THE ROLE OF COMMUNITY IN THE MITIGATION AND ADAPTATION OF THE COVID-19 IN SOUTH KONAWE DISTRICT}

\author{
PENGUATAN PERAN WARGA MASYARAKAT DALAM MITIGASI \\ DAN ADAPTASI MENGHADAPI WABAH COVID-19 DI KABUPATEN \\ KONAWE SELATAN
}

\author{
Suryani $^{1^{*}}$, Loly Subhiaty Idrus ${ }^{1}$, Ruslin $\square$, Rini Hamsidi \\ ${ }^{1}$ Faculty of Pharmacy, Halu Oleo University, Kendari-Indonesia \\ ${ }^{2}$ Department of Health, Faculty of Vocational Study, Universitas Airlangga, Surabaya-Indonesia
}

\section{A B S T R A C T}

Background: Transmission of COVID-19 developed rapidly until the World Health Organization (WHO) established a pandemic status on COVID-19 since March 11, 2020. Various of government efforts in the context of prevention and treatment have been carried out including lockdowns decisision, social distancing and new normal was currently carried out. Objective: This community service activity aims as an effort to increase the knowledge and awareness of South Konawe communities to prevent and fight covid-19 by clean and healthy living behaviors. Method: The implementation of this activity using socialization and persuasive communication online methods via social media instagram and youtube and offline method performed in two categories, small-scale and large-scale at South Konawe. These community service activities are outlined in 4 main programs, GERMAS (Healthy Living Community Movement), GEMAS (Community Movement Using Masks), socialization about TOGA (Family Medicinal Plants), antiseptics and disinfectants. Results: The result of this program is increasing public knowledges about how to improve the immune system, such as consuming nutritious food, consuming herbs which can be processed into an infusion or decocta preparations as well as understand the importance of implementing about prevention of covid-19 in daily life, such wearing masks, antiseptics, and disinfectants and washing hand correctly. Conclusion: This community service activity really helped increase the knowledge and awareness of the community of South Konawe to prevent and fight the corona virus.

\section{A B S T R A K}

Latar belakang: Penularan COVID-19 berkembang pesat hingga Organisasi Kesehatan Dunia (WHO) menetapkan status pandemi pada COVID-19 sejak 11 Maret 2020. Berbagai upaya pemerintah dalam rangka pencegahan, pengobatan dan sebagainya telah dilakukan hingga penerapan lockdown dan social distancing, serta new normal. Tujuan: Kegiatan ini bertujuan sebagai upaya peningkatan pemahaman dan kesadaran masyarakat Kabupaten Konawe Selatan untuk mencegah dan melawan covid-19 melalui perilaku hidup bersih dan sehat. Metode: Metode yang digunakan dalam pelaksanaan kegiatan ini yaitu metode sosialisasi dan komunikasi persuasif secara daring dan secara luring yang dilaksanakan dalam dua kategori, yaitu sosialisasi skala kecil dan skala besar di Kabupaten Konawe Selatan. Kegiatan ini dituangkan dalam 4 program utama yaitu GERMAS (Gerakan Masyarakat Hidup Sehat), GEMAS (Gerakan Masyarakat Menggunakan Masker), penyuluhan tentang TOGA (Tanaman Obat Keluarga), antiseptik dan desinfektan. Hasil: Hasil dari program ini adalah adanya peningkatan pemahaman masyarakat mengenai hal-hal yang dapat meningkatkan sistem imun tubuh, seperti mengkonsumsi makanan bergizi, memanfaatkan herbal yang dapat diolah menjadi sediaan infusa atau dekokta serta memahami pentingnya menerapkan protokol kesehatan untuk covid-19 dalam kehidupan sehari-hari seperti menggunakan masker, antiseptik dan desinfektan serta rajin mencuci tangan. Kesimpulan: Kegiatan pengmas ini sangat membantu menambah pengetahuan dan kesadaran masyarakat Konawe Selatan untuk mencegah dan melawan virus korona.
Scope:

Health

\author{
ARTICLE INFO \\ Received 21 August 2020 \\ Revised 6 December 2020 \\ Accepted 13 May 2021 \\ Online 28 June 2021 \\ *Correspondence (Korespondensi): \\ Suryani \\ E-mail: \\ soerysuer@yahoo.com
}

\section{Keywords:}

COVID-19, GERMAS, GEMAS, TOGA, Antiseptics and Disinfectants

Kata kunci: COVID-19, GERMAS, GEMAS, TOGA, Antiseptik dan Desinfektan 


\section{PENDAHULUAN}

Coronavirus adalah suatu kelompok virus yang dapat menyebabkan penyakit pada hewan atau manusia. Beberapa jenis coronavirus diketahui menyebabkan infeksi saluran nafas pada manusia mulai dari batuk pilek hingga yang lebih serius seperti Middle East Respiratory Syndrome (MERS) dan Severe Acute Respiratory Syndrome (SARS). Coronavirus jenis baru yang ditemukan menyebabkan penyakit Coronavirus Disease 2019 (COVID-19). COVID-19 adalah penyakit menular yang disebabkan oleh jenis coronavirus yang baru ditemukan. Ini merupakan virus baru dan penyakit yang sebelumnya tidak dikenal sebelum terjadi wabah di Wuhan, Tiongkok, bulan Desember 2019 (World Health Organization, 2020).

Virus ini pertama kali muncul di Indonesia pada tanggal 2 Maret 2020 dengan kasus pasien positif sebanyak 2 orang kemudian pasien meninggal pertama tercatat pada tanggal 11 maret 2020. Kondisi terkini, yakni hari terakhir pengambilan data pada 7 Juli 2020, tercatat total kasus COVID-19 meningkat menjadi 66.226 kasus di 30 Provinsi (Kementrian Kesehatan Republik Indonesia, 2020). Sulawesi Tenggara menjadi salah satu provinsi penyumbang kasus positif COVID-19 dengan jumlah awal sebanyak 3 orang hingga 7 Juli total kasus (OVVl-19 meningkat menjadi 487 kasu§ (Satuan Gugus Tugas COVID-19 Sultra , 2020). Kabupaten Konawe Selatan yang merupakan salah satu kabupaten di provinsi Sulawesi Tenggara yang terkonfirmasi kasus positif COVID-19 hingga tanggal 7 Juli 2020 adalah 10 orang (Satuan Gugas Tugas COVID-19 Sultra, 2020).

Upaya pencegahan terhadap peningkatan jumlah penderita COVID-19, seperti yang sudah ditetapkanolehWHO padabulan Maret2020 bahwa semua negara didesak untuk melakukan langkahlangkah efektif untuk mengurangi penularan (Beiu et al., 2020). Oleh karena itu, tindakan pencegahan terhadap jenis penyakit menular tersebut wajib dilakukan secepat mungkin yang sesuai dengan Undang-Undang Nomor 6 Tahun 2018 yaitu tentang Kekarantinaan Kesehatan, dimana masyarakat perlu membatasi kegiatan sosial (Telaumbanua, 20) Penyebaran pada masyarakat pun dapat dikurangi salah satunya dengan menjaga kebersihan tangan secara rutir[(Beiu et al., 2020) juga menjaga kebersihan dari diri dan lingkungan. Menjaga kebersihan diri dan lingkungan dapat dilakukan dengan cara menggunakan antiseptik dan desinfektan. (Larasati \& Haribowo, 2020). Juga upaya penggunaan masker (Greenhalgh et al., 2020). Hal ini perlu dilakukan karena COVID-19 dapat dengan mudah ditularkan melalui jalur pernapasan (tetesan dari orang yang terinfeksi, melalui batuk atau bersin) dan melalui kontak dengan permukaan yang terkontaminasi (Meri et al., 2020).

Masyarakat masih banyak berpikir bahwa penularan COVID-19 masih bisa dihindari hanya dengan menjauhkan diri dari penderita saja, padahal penyakit ini dapat menyebar melalui partikel-partikel yang menempel pada barangbarang disekitarnya. Virus dapat ditularkan dari 1 hingga 2 meter melalui batuk atau bersin. Cara transmisi virus yang lain adalah melalui kontak tangan, ataupun lingkungan yang terkena virus seperti gagang pintu, meja dan kursi. Sanitasi yang dapat dilakukan salah satunya adalah mencuci tangan serta muka dengan teratur. Apabila sanitasi tidak diperhatikan, maka penyebaran akan semakin luas. Dapat dimisalkan seseorang yang terjangkit virus covid bersin dan tidak ditutup baik dengan tisu ataupun diseka menggunakan lengan bagian dalam, dapat menularkan ke orangorang disekitarnya, atau jika seseorang yang terjangkit bersin lalu tanggannya memegang suatu benda yang ada di tempat umum dan orang lain memegangnya, dapat menimbulkan adanya transmisi penyakit (Larasati \& Haribowo, 2020).

Pengetahuanmasyarakattentangpencegahan Covid-19 dengan kepatuhan penggunaan masker memiliki peranan penting dalam mengantisipasi kejadian berulang. Masyarakat harus mengenal, mempelajari dan memahami segala aspek dari penyakit Covid-19 termasuk tanda dan gejala, penyebab, pencetus dan penatalaksanaannya. Pengetahuan memiliki kaitan yang erat dengan keputusan yang akan diambilnya, karena dengan pengetahuan seseorang memiliki landasan untuk menentukan pilihan. Pengetahuan termasuk pentingnya penggunaan masker harus dipegang teguh dan dilaksanakan secara nyata demi mempercepat penghentian penyebaran COVID-19 (Sari et al., 2020).

Untuk mencegah semakin tingginya tingkat penyebaran COVID-19 ini, dapat pula dilakukan dengan banyak mengonsumsi asupan-asupan yang bergizi yang dapat meningkatkan sistem kekebalan tubuh (Hastuti et al., 2016). Salah satu cara mencegah penularan Coronavirus yaitu dengan memanfaatkan tanaman-tanaman obat Keluarga yang disebut dengan istilah TOGA yang memiliki khasiat untuk menjaga dan meningkatkan sistem daya tahan tubuh. Tumbuhan obat merupakan spesies tumbuhan yang sebagian atau seluruh bagian tubuhnya dapat digunakan sebagai ramuan obat-obatan (Emilda et al., 2017). Tujuan pelaksanaan kegiatan Pengabdian Masyarakat Teritegrasi KKN tematik ini adalah untuk meningkatkan pemahaman dan kesadaran masyarakat akan pentingnya adaptasi penerapan protokol kesehatan saat situasi New 
Normal ini, sehingga diharapkan dapat menambah pengetahuan dan kesadaran masyarakat Konawe Selatan untuk men cegah dan melawan COVID-19.

\section{METODE}

Pengabdian masyarakat (Pengmas) ini dilaksanakan di Desa Konda I, Kecamatan Konda, Kabupaten Konawe Selatan, Sulawesi Tenggara pada tanggal 28 Juni 2020. Kegiatan ini diikuti oleh 22 peserta yang merupakan masyarakat Desa Konda I dan 3 aparatur pemerintahan setempat yang diharapkan mampu menerapkan dan mencontohkan kajian mengenai adaptasi dan mitigasi terhadap COVID-19.

Metode yang digunakan pada kegiatan pengmas terintegrasi KKN Tematik adalah metode sosialisasi dan komunikasi persuasif melalui media daring (virtual) dan luring (langsung) mengenai 4 program utama yang berkaitan dengan COVID-19 yaitu GERMAS (Gerakan Masyarakat Hidup Sehat), GEMAS (Gerakan Masyarakat Menggunakan Masker), Sosialisasi mengenai TOGA (Tanaman Obat Keluarga) dan Antiseptik serta Desinfektan. Sosialisasi secara daring dilakukan dengan memanfaatkan media online seperti instagram, whatsup dan youtube. Pelaksaanaan sosialisasi secara daring dilakukan dengan menyajikan materi tiap program dalam bentuk leaflet dan poster yang menarik serta video berdurasi singkat yang dapat diakses melalui akun youtube KKN TEMATIK UHO KONAWE SELATAN 2020 (https://www.youtube. com/channel/UCM5mQgGWhRSA43C5dTAjTmg) dan akun instagram (@kkntematik.konsel) sedangkan sosialisasi secara luring diikuti masyarakat Konawe Selatan dilaksanakan melalui diskusi dan sosialisasi tatap langsung. Sosialisasi tatap langsung dilakukan dengan dua cara yaitu sosialisasi pada masyarakat sekitar dalam skala kecil dan skala besar. Sosialisasi skala kecil dilaksanakan dengan cara setiap mahasiswa mengunjungi maksimal dua rumah (rumah keluarga atau tetangga terdekat) kemudian memberikan leaflet dan edukasi secara langsung serta menempel poster dibeberapa titik rumah warga Konawe Selatan sedangkan sosialisasi skala besar dilaksanakan di Balai Desa Konda Satu, Kecamatan Konda Kabupaten Konawe Selatan dengan sasaran lebih banyak warga masyarakat Konawe Selatan ikut terlibat yaitu sebanyak 25 warga. Dalam sosialisasi tersebut, warga masyarakat juga diberi edukasi terkait empat program utama KKN Tematik ini.

Empat program KKN Tematik ini meliputi:

a. Program GERMAS adalah program yang dicanangkan oleh Kementerian Kesehatan yang kemudian diaplikasikan oleh mahasiswa dalam bentuk sosialisasi gizi seimbang dalam rangka meningkatkan imunitas tubuh, sosialisasi mengenai pentingnya olahraga yang cukup dan rutin, serta sosialisasi mengenai Perilaku Hidup Bersih dan Sehat.

b. Program GEMAS berupa meningkatkan pemahaman masyarakat mengenaipentingnya penggunaaan masker, tata cara penggunaan masker yang baik dan jenis-jenis masker, juga perawatan dan penggunaannya.

c. Program TOGA berupa sosialisasi yang terdiri atas pengenalan minuman untuk meningkatkan sistem imunitas alami seperti infusa dan dekokta yang berasal dari tanaman jahe dan VCO (Virgin Coconut Oil) yang juga mencakup cara pembuatan dan manfaatnya

d. Program Antiseptik dan Desinfektan berupa penjelasan mengenai perbedaan antiseptik dan desinfektan, yang terdiri dari perbedaan penggunaan/aplikasi dan cara pembuatannya.

\section{HASIL DAN PEMBAHASAN}

Kegiatan pengabdian masyarakat terintegrasi KKN Tematik bertujuan untuk menunjukan peran mahasiswa terhadap masyarakat melalui empat program utama yaitu: (1) GERMAS; (2) GEMAS; (3) TOGA; dan (4) Antiseptik dan Desinfektan.

Gerakan Masyarakat Hidup Sehat (GERMAS) merupakan gerakan nasional yang diprakarsai oleh Presiden RI yang bertujuan untuk memasyarakatkan budaya hidup sehat serta meninggalkan kebiasaan dan perilaku masyarakat yang kurang sehat. Kegiatan sosisalisai dilakukan dengan mengedukasi masyarakat langkahlangkah hidup sehat seperti melakukan aktivitas fisik, membiasakan berjemur setiap hari, budaya konsumsi buah dan sayur, tidak merokok, tidak mengonsumsi minuman beralkohol, dan menjaga kebersihan lingkungan terutama sirkulasi udara di rumah. Selain itu juga ditekankan pentingnya mencuci tangan menggunakan air mengalir dan memakai sabun setelah melakukan aktivitas dan tidak menyentuh mata, hidung dan mulut dengan tangan yang kotor. Cara mencuci tangan yang benar juga diperagakan secara langsung dan terlihat antusiasme masyarakat yang ikut memperagakan cara mencuci tangan yang benar sehingga diharapkan dengan adanya sosialisasi ini, masyarakat dapat menerapkan di kehidupan sehari-hari dan meninggalkan kebiasaan mencuci tangan yang lama(Gambar 1$)$.

GEMAS atau Gerakan Masyarakat Menggunakan Masker adalah salah satu gerakan yang dipelopori oleh Direktorat Promosi Kesehatan dan Pemberdayaan Masayarakat untuk memasyarakatkan budaya penggunaan masker 
baik dalam kondisi sakit maupun sehat. Dalam sosialisasi ini, beberapa edukasi yang dipaparkan berlandaskan pada pengamatan mahasiswa terhadap masyarakat Konawe Selatan yang terlihat belum sepenuhnya mengetahui fungsi dari penggunaan masker (Gambar 2). Masih terlihat beberapa masyarakat yang tidak menggunakan masker dan beberapa masyarakat lainnya terlihat menggunakan masker tidak tepat, sehingga masyarakat perlu diberikan pemahaman terebih dahulu cara penularan virus corona yang dapat menular lewat droplet seseorang saat seseorang berbicara, bersin atau batuk serta fungsi dari penggunaan masker itu sendiri. Edukasi tambahan lainnya yaitu mengenai cara penggunaan masker yang tepat, perbedaan masker medis dan non medis.

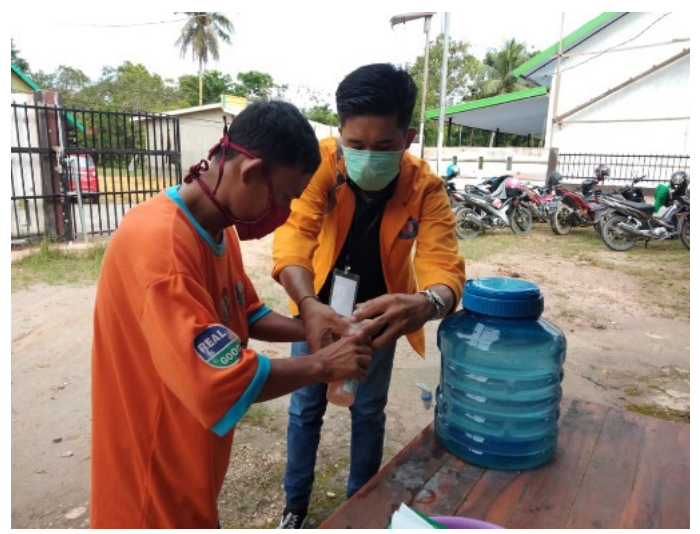

Gambar 1. Sosialisasi dan Praktik Cara Mencuci Tangan yang Baik

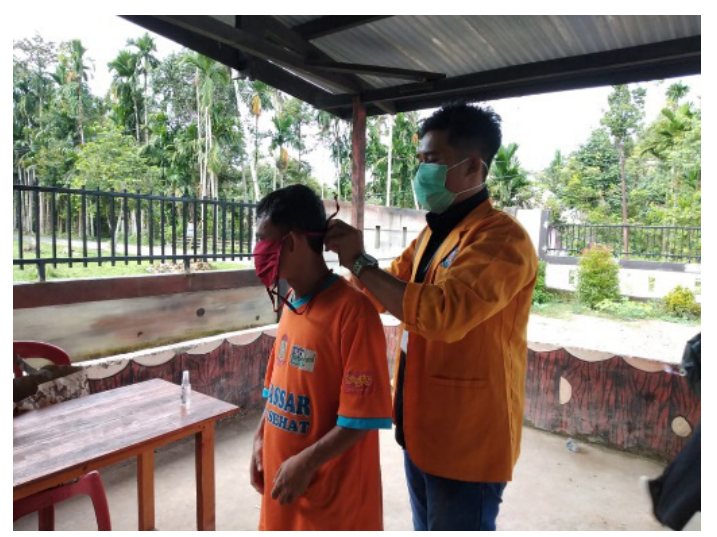

Gambar 2. Sosialisasi dan Praktik Penggunaan Masker yang Baik

Tanaman obat keluarga (TOGA) adalah salah satu bentuk upaya promosi kesehatan masyarakat pada level keluarga dengan memanfaatkan pekarangan rumah sebagai sarana budidaya tanaman obat. Berdasarkan hasil diskusi saat sosialisasi berlangsung, rata-rata warga di Desa Konda I telah memahami konsep TOGA, yaitu tanaman obat yang ditanam di pekarangan rumah namun masyarakat terlihat kurang memahami akan manfaat dari tanaman-tanaman tersebut dan cara pengolahannya. Pemberian edukasi mengenai TOGA dititikberatkan pada tanamantanaman yang sering digunakan masyarakat sehari-hari yang secara empiris maupun yang telah dibuktikan dari beberapa penelitian berpotensi untuk menjaga dan meningkatkan daya tahan tubuh misalnya kunyit, jahe, temulawak, kencur dan sereh (Novianto et al., 2020 ; Saputri et al., 2018; Soleh, 2019; Dash et al., 2017) Informasi lain yang diberikan yaitu mengenai cara pengolahan tanaman tersebut menjadi sediaan infusa dan dekokta. Infusa dan dekokta merupakan sediaan cair yang diperoleh dari tanaman dengan cara direbus dalam waktu perebusan yang telah ditentukan. Perbedaan antara keduanya yaitu hanya terletak pada watu perebusannya saja, infusa selama 15 menit dan dekokta selama 30 menit. Selain edukasi mengenai TOGA, masyarakat juga diperkenalkan dengan VCO. Bagi masyarakat Konawe Selatan,VCO belum dikenal luas manfaat dan cara pengolahannya sehingga dengan adanya sosialisasi ini diharapkan masyarakat mampu mengolah mandiri dan memanfaatkan VCO sebagai salah satu suplemen yang digunakan setiap hari dalam rangka meningkatkan sistem kekebalan tubuhnya (Gambar 3).

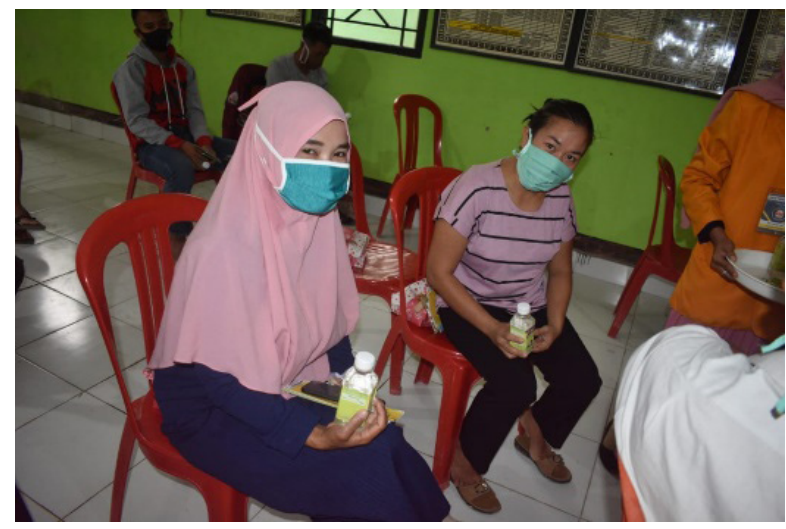

Gambar 3. Pengenalan produk VCO kepada masyarakat

Kegiatan sosialisasi ini bertujuan untuk mengenalkan kepada masyarakat Konawe Selatan mengenai antiseptik dan desinfektan serta perbedaan dan cara pembuatannya. Antiseptik dan desinfektan merupakan zat kimia yang digunakan untuk mendesinfeksi/membunuh mikroorganisme patogen yang dapat menginfeksi manusia. Perbedaannya yaitu antiseptik digunakan pada kulit atau jaringan hidup, sedangkan desinfektan pada objek tidak hidup. Sehingga masyarakat tidak salah kaprah menggunakan desinfektan pada manusia. Centers of Disease Control and Prevention (2019) menyatakan mencuci tangan menggunakan sabun lebih efektif membunuh mikroorganisme dibandingkan dengan menggunakan handsanitizer sehingga perlu diinformasikan bahwa penggunaan 
handsanitizer disarankan hanya digunakan sebagai alternatif ketika cuci tangan menggunakan sabun tidak memungkinkan (Gambar 4).

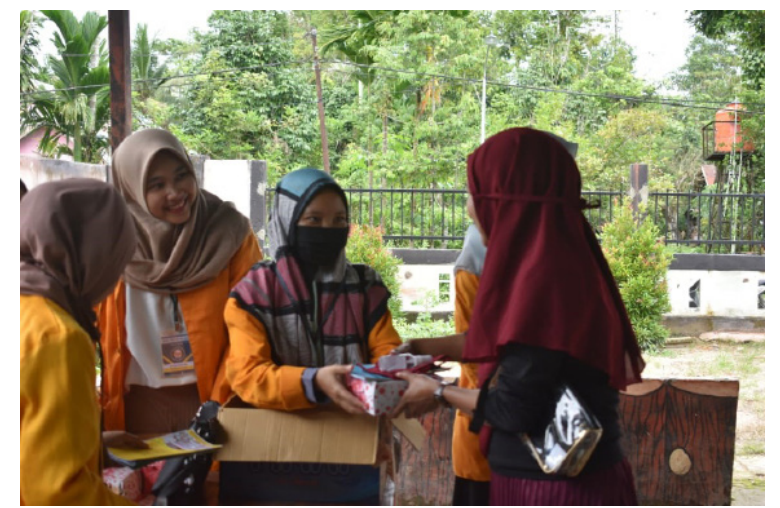

Gambar 4. Pembagian Antiseptik (Handsanitizer) kepada masyarakat

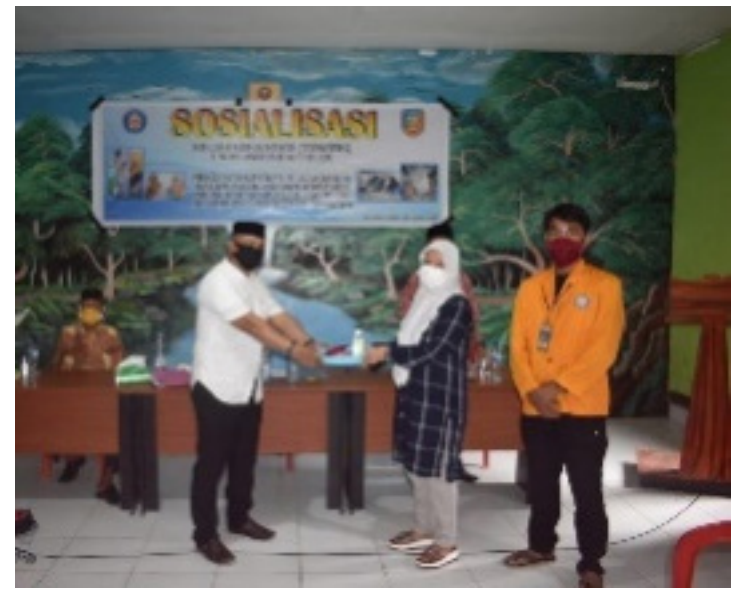

Gambar 5. Penyerahan Masker, Antiseptik dan VCO pada Pemerintah Desa Konda Satu

Pada akhir kegiatan dilakukan pembagian masker, handsanitizer dan VCO bagi masyarakat yang mengikuti kegiatan ini, sehingga diharapkan mendorong semangat masyarakat untuk menerapkan informasi dan edukasi yang telah diberikan serta patuh pada protokol kesehatan saat beraktivitas. Akibat keterbatasan jumlah peserta saat sosialisasi, pendistribusian masker, handsanitizer dan VCO ini diamanahkan ke pemerintah setempat khususnya Tim Gugus Tugas Desa Konda Satu untuk dibagikan pada masyarakat yang tidak menghadiri sosialisasi (Gambar 5).

\section{KESIMPULAN DAN SARAN}

Berdasarkan kegiatan yang telah dilakukan dapat disimpulkan bahwa program utama KKN yang meliputi GERMAS (Gerakan Masyarakat Hidup Sehat), GEMAS (Gerakan Masyarakat Menggunakan Masker), TOGA (Tanaman Obat Keluarga) dan antiseptik dan desinfektan telah dilaksanakan melalui penyuluhan melalui media massa dan sosialisasisecaralangsungpadakeluarga binaan maupun sosialisasi yang dilakukan di Desa Konda Satu. Penyuluhan dan sosialisasi secara langsung diharapkan membantu meningkatkan kesadaran masyarakat Konawe Selatan untuk mencegah dan melawan penyebaran COVID-19.

Jumlah kasus teridentifikasi COVID-19 tiap harinya selalu bertambah., tetapi kegiatan seharihari sudah dilaksanakan seperti biasa (New Normal). Penyuluhan melalui media massa seperti sosial media diharapkan dapat membantu dan mempermudah masyarakat dalam meningkatkan pengetahuan tentang COVID-19. Kegiatan yang dilakukan di Desa Konda Satu terkait penyuluhan segala aspek tentang COVID-19 diharapkan juga mampu mempermudah masyarakat untuk memerhatikan aspek-aspek kesehatan dalam proses peningkatan edukasi terkait COVID-19.

\section{UCAPAN TERIMA KASIH}

Terima kasih diucapkan kepada LPPM Universitas Halu Oleo yang telah mendanai keberlangsungan kegiatan ini. Terima kasih pula untuk Dosen Pembimbing Lapangan, Kepala Desa Konda Satu, LPM Desa Konda Satu, Ketua BPD Desa Konda Satu, dan Peserta KKN Tematik UHO 2020 Kabupaten Konawe Selatan, dan juga kepada semua pihak yang terlibat. Penulis menyatakan tidak ada konflik kepentingan dengan pihak-pihak yang terkait dalam kegiatan pengabdian kepada masyarakat ini.

\section{DAFTAR PUSTAKA}

Beiu C., et al. 2020. Frequent Hand Washing for COVID-19 Prevention Can Cause Hand Dermatitis: Management Tips From Frequent hand Washing to hand Dermatitis. Cureus Vol. 12(4).

Dash, S., et al. 2017. Edible plant-derived essential oils synergistically enhance the Th1, Th2 and anti-inflammatory cytokines in neonatal cord blood monocytic cell line, Food and Agricultural Immunology Vol. 29(1). Pp. 346357.

Emilda, Muslihatul H., \& Heriyati, 2017, Analisis Pengetahuan Masyarakat Tentang Pemanfaatan Tanaman Obat Keluarga (Studi Kasus Kelurahan Situgede, Kecamatan Bogor Barat), Sainmatika: Jurnal Ilmiah Matematika dan Ilmu Pengetahuan Vol. 14(1). Pp. 11-21.

Greenhalg T., et al. 2020. Face Masks foe The Oubluc During The COVID-19 Crisis. BMJ; 369. Retrived from https://www.bmj.com/ content/369/bmj.m1435.long. 
Hastuti, N.P., Yulia S., \& Muhammad K.B.I. 2019. Gambaran Pelaksanaan Kegiatan Gerakan Masyarakat Hidup Sehat (GERMAS). Jurnal Ilmiah STIKES Kendal Vol. 9(2). Pp. 141-148.

Kementrian Kesehatan RI. 2020. Panduan Gizi Seimbang Pada Masa Covid-19. Jakarta: Kementerian Kesehatan RI.

Larasati, A.L, \& Haribowo, C. 2020. Penggunaan Desinfektan dan Antiseptik pada Pencegahan Penularan Covid-19 di Masyarakat. Majalah Farmasetika Vol. 5(3). Pp. 137-145.

Meri, et al. 2020. Pemberdayaan Masyarakat dalam Penggunaan Handsanitzer dan Masker Sebagai Upaya Prefentif Terhadap COVID-19. Bantenese: Jurnal Pengabdian Masyarakat Vol. 2(1). Pp. 26-33.

Novianto, F., et al. 2020. Pengaruh Formula Jamu Temulawak, Kunyit dan Meniran Terhadap Kebugaran Jasmani : Suatu Studi Klinik. Media Litbangkes Vol. 30(1). Pp. 37-44.

Saputri, G.Z., Haafizah, D., \& Widyasari, P. 2018. Optimalisasi pemanfaatan Jahe (Zingiber officinale) dan Rosella (Hibiscus sabdarifa) sebagai minuman kesehatan di Madrasah Muallimin Muhammadiyah Yogyakarta. Jurnal
Pemberdayaan: Publikasi Hasil Pengabdian Kepada Masyarakat Vol. 2(2). Pp. 241-248.

Sari, D.P., Nabila S, \& Atiqoh. 2020. Hubungan Antara Pengetahuan Masyarakat Dengan Kepatuhan Penggunaan Masker Sebagai Upaya Pencegahan Penyakit Covid-19. INFOKES: Jurnal Ilmiah Rekam Medis dan Informatika Kesehatan Vol. 10(1). Pp. 52-55.

Satuan Gugas Tugas COVID-19 Sultra. 2020. 'Data Kasus Positif Menurut Golongan Umur dan Jenis Kelamin'.

Soleh, \& Megantara, S. 2019. Karakteristik Morfologi Tanaman Kencur (Kaempferia galanga L.) dan Aktivitas Farmakologi. Jurnal Farmaka Vol. 17(2). Pp. 256-262.

Telaumbanua, Dalinama. 2020. Urgensi Pembentukan Aturan Terkait Pencegahan Covid-19 di Indonesia. Qalamuna: Jurnal Pendidikan, Sosial, dan Agama Vol. 12(1). Pp. 59-70.

World Health Organization. 2020. Rational Use Of Personal Protective Equipment For Coronavirus Disease (Covid-19), Geneva: World Health Organization 2020. 